\title{
Defining features of the hair cell mechanoelectrical transducer channel
}

\author{
Robert Fettiplace
}

Received: 8 April 2009/Revised: 8 May 2009/Accepted: 12 May 2009/Published online: 28 May 2009

(C) The Author(s) 2009. This article is published with open access at Springerlink.com

\begin{abstract}
This review summarizes current knowledge of the hair cell mechanotransducer channel, the ion channel responsible for detecting mechanical stimuli in the inner ear and one of the few channels whose molecular structure is still unknown. Several candidate proteins have been proposed, especially members of the transient receptor potential (TRP) channel family, but all have so far failed in one test or another. Furthermore, none has biophysical properties exactly matching the native channel. The defining features of the native mechanotransducer channel are documented, including ionic permeability, channel structure inferred from blocking agents, diversity in channel conductance, and regulation by $\mathrm{Ca}^{2+}$, which are compared with a potential candidate, TRP channels of the polycystin family. The strengths and weaknesses of a TRP channel contender are discussed.
\end{abstract}

Keywords Cochlea $\cdot$ Calcium $\cdot$ Hair cell $\cdot$ Stereocilia $\cdot$ TRPP channels $\cdot$ Polycystin $\cdot$ Tip link

\section{Introduction}

Ion channels located on the plasma membrane dictate the electrical behavior of most cells, particularly neurons, and are the main mediators of fast signal transduction. For example, voltage-dependent calcium channels convert excursions in membrane potential into intracellular calcium transients, glutamatergic channels account for fast excitato-

R. Fettiplace $(\bowtie)$

Department of Physiology,

University of Wisconsin Medical School,

185 Medical Sciences Building, 1300 University Avenue,

Madison, WI 53706, USA

e-mail: fettiplace@physiology.wisc.edu ry synaptic transmission, and cyclic nucleotide-gated channels are the last step in transduction in visual and olfactory receptors. Over the last 20 years, the structure and gating mechanisms of a number of ion channels, either voltage-dependent or ligand-activated, have been substantially elucidated [37]. However, the molecular identity of a third class of ion channel, responding to mechanical deformations of a cell, is still largely unknown in eukaryotes. These channels are employed ubiquitously in cutaneous sensation, in internal organs such as baroreceptors and in the inner ear. A prime example is the mechanoelectrical transducer (MET) channel in cochlear hair cells, which detects minute mechanical stimuli elicited by sound pressure fluctuations. The MET channel is associated with an accessory specialization, the hair bundle, a cluster of modified microvilli known as stereocilia, that project from the top of the sensory cell. Hair cell transduction has been extensively studied in both mammals and non-mammals and is mediated by sub-micron deflections of the hair bundle which activate MET channels in the stereocilia [26]. Compared with other types of ion channel, however, little is known about the molecular composition of the MET channel or how the stimulus energy is coupled to channel opening [10]. This is an important lacuna in our understanding of hair cell mechanisms and hearing. This review summarizes present knowledge of the MET channel against which any channel contender should be judged.

\section{Channel location and gating - the fastest channel known}

During hair cell transduction, the MET channel is thought to be activated by tension in tip links connecting the apex of one stereocilium with the side wall of its neighbor (Fig. 1). Deflection of the hair bundle towards its taller edge 


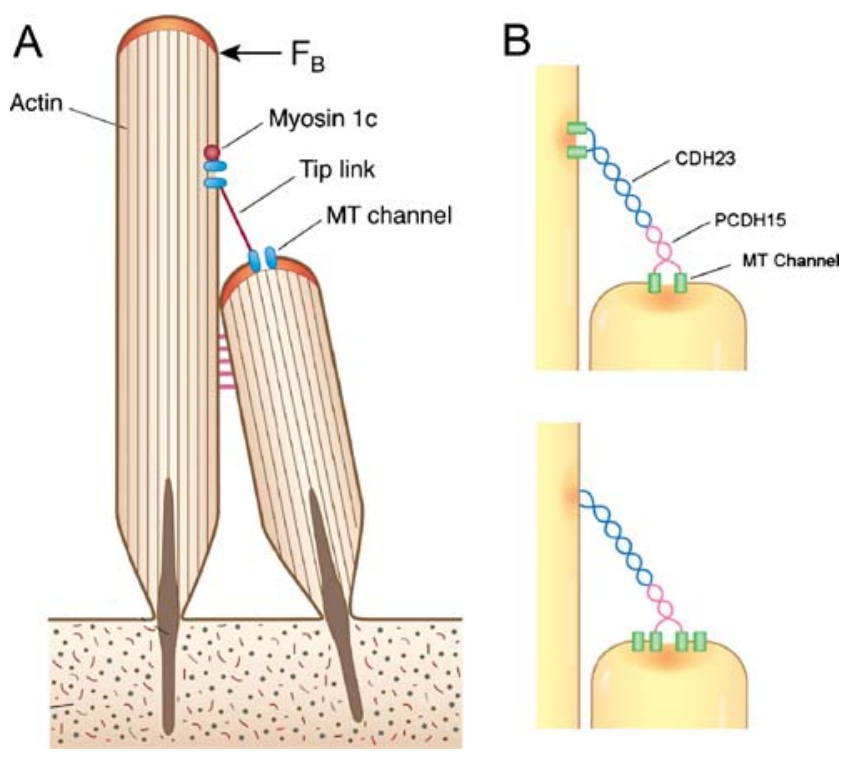

Fig. 1 Localization of the MET channel relative to the tip link. a Application of force $\left(F_{\mathrm{B}}\right)$ to the hair bundle increases tension in tip links connecting contiguous stereocilia and leads to stimulation of the mechanoelectrical transducer (MET) channels. In a common cartoon, channels are present at both ends of the tip link which is kept taut by the climbing activity of a myosin $1 \mathrm{c}$ motor at the upper end. b Two possible channel locations. The tip link is composed of dimers of cadherin 23 (CDH23) joined to dimers of protocadherin 15 (PCDH15) [45]. Recent imaging of $\mathrm{Ca}^{2+}$ influx during stimulation [4] suggests that MET channels are present only at the lower ends of the tip links, (bottom figure) where they could theoretically interact with the Cterminus of protocadherin 15 . On this scheme, it is unknown how myosin $1 \mathrm{c}$ might serve as the adaptation motor

increases tip link tension and opens channels through which flows the transducer current. This generates an analog waveform, the receptor potential, which is relayed synaptically to auditory nerve fibers where it initiates a volley of action potentials. For an abrupt displacement of the hair bundle, the transducer current in non-mammals such as frog or turtle $[12,13,65]$ develops with a time constant decreasing with stimulus amplitude (range 500-50 $\mu$ s). The acceleration of activation kinetics with stimulus amplitude is expected if the mechanical stimulus modulates the free energy difference between the open and closed states of the channel. In mammalian cochlear hair cells, the activation time constant is more than an order of magnitude smaller, being indistinguishable from the experimentally limited rise time of the displacement step [65, 68] which under in vitro conditions can have a time constant of $\sim 20 \mu$ s at best [68]. It seems likely that the activation time constant of the mammalian MET channel, when extrapolated to body temperature $\left(Q_{10}=2.0 ;[12,13]\right)$, must be less than $10 \mu \mathrm{s}$ in vivo, making it the ion channel with the fastest known gating kinetics. The MET channel in mammals has more rapid kinetics than in non-mammals presumably because the hair cells must respond to higher stimulation frequencies up to $100 \mathrm{kHz}$; this difference implies a structural change to the channel.

The MET channel also undergoes several phases of $\mathrm{Ca}^{2+}$ dependent adaptation $[1,13]$, the quickest component of which also exhibits a kinetic difference between nonmammals, in which the adapting time constant is $\approx 1 \mathrm{~ms}$, and mammals where it is $\approx 0.1 \mathrm{~ms}[26,65,68] . \mathrm{Ca}^{2+}$ entering via the channel is thought to bind to a site on or near the channel to promote channel reclosure and fast adaptation [13, 38, 72]. The reported time constants of activation and adaptation should be regarded as upper limits as it is conceivable that during stimulation other ratelimiting steps are imposed by the hair bundle mechanics. For example, non-coherent motion of the stereocilia because of inadequacies in stimulation or viscoelastic properties in the inter-ciliary linkages could slow the observed kinetics. Nevertheless, the gating kinetics documented are sufficiently fast to argue for a direct mechanical connection to the channel. A model of transduction, devised from characterizing hair bundle mechanics [38], proposes that MET channels are opened by force applied via elastic elements known as "gating springs", which are stretched when the hair bundle is deflected. One end of the spring is extended by tension in the tip link (which is probably too rigid to be the gating spring [44]), while the other end is attached to the channel's hypothetical gate. A conclusion from this model is that the channel gate undergoes a large motion with a swing of 2-4 nm during opening $[9,38]$. If taken at face value, such modeling implies that there are large, fast rearrangements of the channel protein during opening.

How is the tip link related to the MET channel? The tip links are $150-180 \mathrm{~nm}$ in length [28] and thought to be composed of a twisted pair of cadherin 23 molecules joined near their N-termini to a pair of protocadherin 15 molecules (Fig. 1; [45]). From imaging of $\mathrm{Ca}^{2+}$ influx through MET channels during hair bundle stimulation, the channels have been localized near the tops of the stereocilia [20,53], but their relationship to the tip link has been unclear. It was previously suggested that channels were present at both ends of the tip link [20] and this hypothesis was incorporated into an attractive model of channel regulation [31]. The model proposed that Myo-1c motors, climbing up actin filaments in the stereocilia, were controlled by $\mathrm{Ca}^{2+}$ influx through channels at the top of the tip link. These motors are thought to be responsible for maintaining the tip links taut and for mediating a form of adaptation slower than that directly involving the channel (Fig. 1). However, recent high speed confocal imaging of $\mathrm{Ca}^{2+}$ influx in mammalian cochlear hair cells [4] has revealed the absence of $\mathrm{Ca}^{2+}$ signals in the tallest row of stereocilia, prompting the conclusion that the MET channels are restricted to the lower end of the tip links. Thus, inner hair cells with three 
rows of stereocilia were found to possess MET channels only in the middle and shortest rows. A comparison of the size of the transducer current with the number of tip links or functional stereocilia suggested that each link was connected to two channels [3, 4]. This conclusion is satisfying because of the asymmetry in the tip link structure. A plausible functional arrangement might therefore be that each channel connects directly with the intracellular C-terminus of a protocadherin 15 molecule comprising the lower end of the tip link. A direct interaction between protocadherin 15 and the MET channel might be exploited to isolate the channel using yeast two hybrid methods.

\section{Insights into the structure from channel permeability and block}

The MET channel is a large conductance cation channel with a permeability sequence of $P_{\mathrm{Ca}}>P_{\mathrm{Li}}>P_{\mathrm{Na}} \approx P_{\mathrm{K}}>$ $P_{\mathrm{Rb}}>P_{\mathrm{Cs}}$ (Eisenman permeability sequence XI, corresponding to a strong-field strength site; [59]). This means that permeation is dominated by the ion's interaction with a negative site in the pore rather than by removal of the hydration shell. The channel is preferentially permeable to divalent metal cations [11] such as $\mathrm{Ca}^{2+}$ and $\mathrm{Mg}^{2+}$ and, based on measurements of reversal potential, $P_{\mathrm{Ca}} / P_{\mathrm{Na}}$ is $\approx 5: 1$ in both non-mammals [59] and mammals [3]. Using this permeability ratio, the channel would be expected to carry $15 \%$ of the total transducer current in $1.5 \mathrm{mM}$ extracellular $\mathrm{Ca}^{2+}$ and $0.2 \%$ of the current in an endolymphatic $\mathrm{Ca}^{2+}$ of $20 \mu \mathrm{M}$. However, there have been claims that $\mathrm{Ca}^{2+}$ contributes a significantly larger fraction of the current under these conditions $[43,63]$ implying a $P_{\mathrm{Ca}} / P_{\mathrm{Na}}$ greater than $5: 1$. In the intact inner ear, when the hair bundles are bathed in endolymph, the transducer current will be carried predominantly by $\mathrm{K}^{+}$ions with a minor contribution from $\mathrm{Ca}^{2+}$ [63]. The channel is unusual in exhibiting a significant permeability to large organic cations such as choline ( $\left.P_{\text {choline }} / P_{\mathrm{Na}}=0.27 ;[59]\right)$ and tetraethyl ammonium (TEA) ions $\left(P_{\mathrm{TEA}} / P_{\mathrm{Na}}=0.1 ;[22,59]\right.$. A comparison of permeabilities using a series of trialkyl and tetralkyl ammonium derivatives indicated an effective pore size of $1.2 \mathrm{~nm}$ [22] in accord with the large single-channel conductance. This size of pore is not shared with other non-selective cation channels with high $\mathrm{Ca}^{2+}$ permeability, such as the acetylcholine receptor and cyclic nucleotide-gated channels both of which are effectively impermeable to TEA [21,61].

The MET channel is blocked by an assortment of agents $[22,26]$ and, where comparisons can be made, results from non-mammals (frogs, chick, turtle) largely agree with measurements on mammals suggesting a common pore structure. High affinity blockers include extracellular $\mathrm{La}^{3+}$ (half blocking concentration, $\left.\mathrm{IC}_{50}=4 \mu \mathrm{M}\right), \mathrm{Gd}^{3+}\left(\mathrm{IC}_{50}=\right.$ $3 \mu \mathrm{M})$ and ruthenium red $\left(\mathrm{IC}_{50}=3 \mu \mathrm{M}\right)$ that block many transient receptor potential (TRP) and mechanically sensitive channels $[22,46]$. Other more bulky polyvalent cations able to block the channel from its external face include amiloride $\left(\mathrm{IC}_{50}=50 \mu \mathrm{M}\right.$; $\left.[42,66]\right)$, dihydrostreptomycin (DHS; $\mathrm{IC}_{50}=10-70 \mu \mathrm{M}$; [51, 59, 62]), FM1-43 $\left(\mathrm{IC}_{50}=\right.$ $1 \mu \mathrm{M}$; [29]) and curare $\left(\mathrm{IC}_{50}=2-6 \mu \mathrm{M}\right.$; [22, 32]. The channel is also blocked by $\mathrm{Ca}^{2+}$ with an $\mathrm{IC}_{50}$ of $1 \mathrm{mM}[14$, 63]. This action of $\mathrm{Ca}^{2+}$ is notable because it implies that the divalent cation can both block and permeate the channel as would occur if the site of interaction were negative charges within the selectivity filter: because of the permeability sequence, $\mathrm{Ca}^{2+}$ lingers longer in the pore. However, similar behavior occurs with large organic blockers like DHS [54] and FM1-43 [29] which are also partially permeable when applied externally. Hair cell accumulation of FM1-43 can be visualized by the increase in hair cell fluorescence as the dye that has entered via the MET channel binds to intracellular membranes [29, 55]. Neither agent is as effective when applied intracellularly (e.g., about 100-fold higher concentrations of DHS are needed to elicit the same inhibition; [54]) implying differential access to the blocking site within the channel from the outside and inside. This has led to the notion of a funnel-shaped channel [70], possessing a wide extracellular mouth or vestibule that can more easily accommodate large molecules with the charged residue on the blocker extending into the pore. The vestibule has room for an elongated FM1-43 molecule, $2.2 \mathrm{~nm}$ long but only $0.8 \mathrm{~nm}$ maximum end-on diameter [70], which is able to traverse the pore. However, the vestibule cannot accommodate the analog FM3-25, which has a fan-shaped tail of broader cross section and neither blocks nor permeates the MET channel [29].

In spite of a potential asymmetry to the MET channel structure, the current-voltage relationship for the channel in normal extracellular solution $\left(\mathrm{Na}^{+}\right.$-containing saline with $1.5 \mathrm{mM} \mathrm{Ca}^{2+}$ ) is approximately linear between $\pm 100 \mathrm{mV}$ $[14,52]$; a modest inward rectification is acquired if the extracellular $\mathrm{Ca}^{2+}$ concentration is reduced to $20 \mu \mathrm{M}$, similar to that in endolymph [3]. However, a pronounced non-linearity to the current-voltage relationship appears in the presence of the divalent channel blockers DHS [51, 54, $58,59]$ or amiloride [66], implying voltage dependence to their blocking action. For both agents, suppression of the transducer current is maximal at a membrane potential around $-70 \mathrm{mV}$ but is relieved on depolarization beyond $0 \mathrm{mV}$. This would occur if the blocker needed access to a negative binding site within the electrical field. By modeling the voltage dependence, it has been estimated that the site is located at a fractional distance in the field from the external face, $\delta_{\mathrm{b}}$, of 0.79 for DHS and 0.44 for 
amiloride [70]; a value for $\delta_{\mathrm{b}}$ of 0.45 has also been inferred based on the voltage dependence of permeation by various organic cations [22]. The reason for the different values for $\delta_{\mathrm{b}}$ is unclear and it is possible that there are a series of negative charges within the vestibule surrounding the selectivity filter that influence the voltage sensitivity of permeation and block. Using the dimensions of the nonblocking analog, FM3-25, the distance of the negative binding site from the external surface was estimated to be $\sim 2 \mathrm{~nm}$. The efficacy of both amiloride and DHS is also reduced by hyperpolarization negative to $-100 \mathrm{mV}$ which has been attributed to exit of the blockers through the selectivity filter into the cell [70]. Amiloride, DHS, and FM1-43 all therefore behave as permeant blockers.

\section{Channel conductance - a surprising variation}

Characterization of single MET channel properties cannot be achieved in hair cells by employing conventional cellattached or detached patch methods because it precludes delivering appropriate physiological stimuli. However, it has been possible to record unitary events by destroying most of the extracellular connections to the channels (the tip links) by brief exposure to sub-micromolar $\mathrm{Ca}^{2+}$; this procedure probably severs the tip links at the junction between cadherin-23 and protocadherin- 15 . One or a few channels are spared by this approach and can be measured in whole-cell mode because of their large unitary conductance $>100 \mathrm{pS}[14,30,59,64]$. Individual channels recorded in this manner show all the features of the macroscopic MET current (Fig. 2a). They can be activated by sub-micron displacements of the hair bundle, they exhibit adaptation, and they are blocked by DHS and by millimolar $\mathrm{Ca}^{2+}$. They have mean open times of under $1 \mathrm{~ms}$ which decrease with stimulus amplitude [14] and are inversely related to external $\mathrm{Ca}^{2+}$ concentration (i.e., longer open times in lower $\mathrm{Ca}^{2+}$ ). Besides the large fast conductance level, some cells also display a long-lived subconductance state about $40 \%$ of the size of the chief level $[14,64]$.

A surprising property of the MET channels recorded in turtle auditory cells is a variable conductance that depends upon the localization of the hair cell in the cochlea, increasing from 100 to $300 \mathrm{pS}$ (in $0.05 \mathrm{mM} \mathrm{Ca}^{2+}$ ) along the tonotopic axis from low-frequency to high-frequency end of the papilla (Fig. 2b). As a consequence of this variation, both the size of the macroscopic current and the rate of fast adaptation become larger towards the high frequency end [64]. The change in fast adaptation can be explained if its rate grows with the amount of $\mathrm{Ca}^{2+}$ entering the stereocilia [63], the $\mathrm{Ca}^{2+}$ influx increasing with channel conductance. This notion is supported by the observation

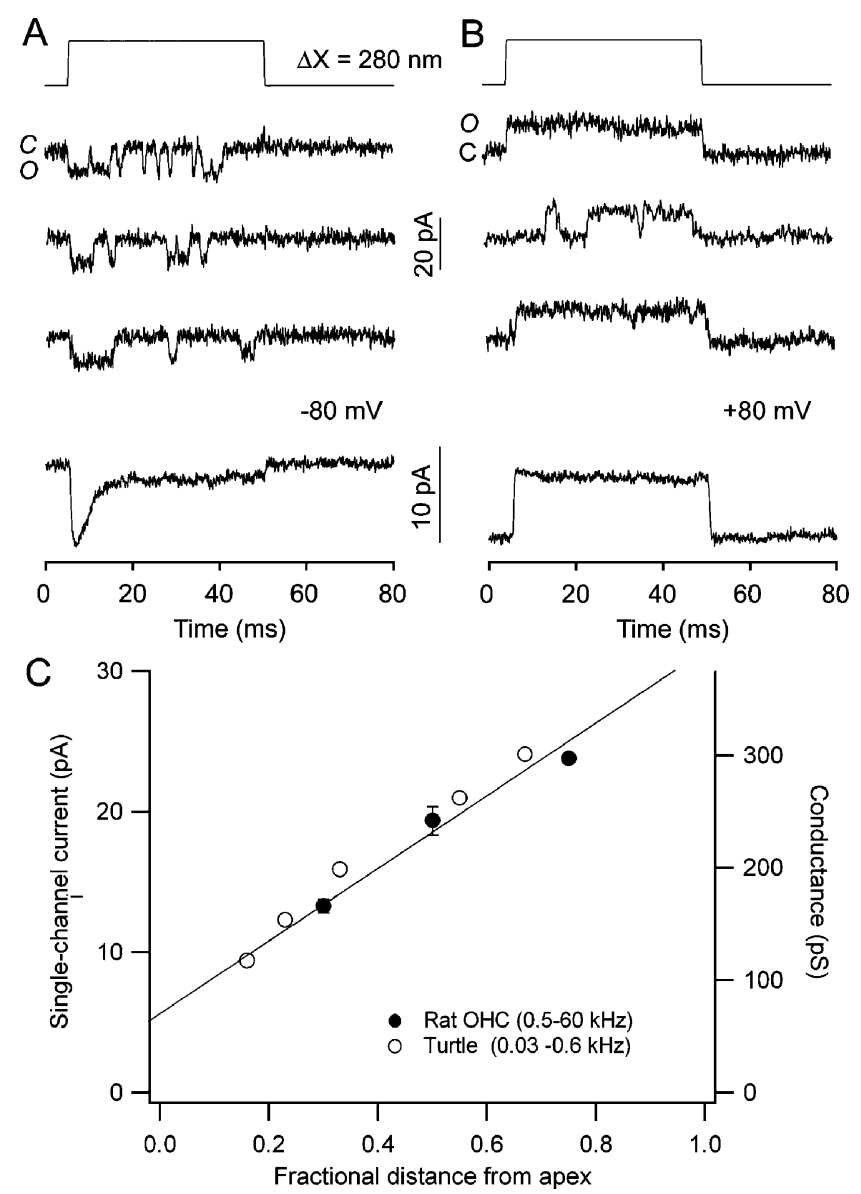

Fig. 2 Mechanoelectrical transducer channels. a Single MET channel events recorded in a turtle auditory hair cell during hair bundle deflection of $280 \mathrm{~nm}$. Three traces depict channel opening at the start of the step, the ensemble average current (below) displaying adaptation with a time constant of $3.5 \mathrm{~ms}$. b When the holding potential is switched from -80 to $+80 \mathrm{mV}$ to prevent $\mathrm{Ca}^{2+}$ influx, the channels remain open throughout the step and the average current shows no adaptation. Measurements were made in $2.8 \mathrm{mM}$ external $\mathrm{Ca}^{2+}$. $\mathbf{c}$ MET channel amplitude as a function of hair cell location in the cochlea, expressed as the fractional distance from the apical low frequency end, in turtle (open circles) and rat (filled circles). The values are given for a low external $\mathrm{Ca}^{2+}$ concentration $(30-50 \mu \mathrm{M})$ that does not block the channel. Results in turtle from [64]; those in rat from [3] and unpublished, corrected for removal of $\mathrm{Ca}^{2+}$ block. Each of the rat points is the mean $( \pm 1 \mathrm{SD})$ of three cells

that the time constant of adaptation seen in single channel events depends on channel conductance [64]. In the mammalian cochlea, the situation is more complicated and MET channel properties differ between inner and outer hair cells [3]. The outer hair cells, which fulfill a role in cochlear amplification by virtue of their unique electromechanical attributes [18], show a tonotopic variation in channel conductance similar to turtle auditory hair cells. The amplitude of the macroscopic current and the rate of adaptation increase too with frequency $[36,65]$. The change in conductance, when expressed as a function of the 
fractional distance of the hair cell along the basilar membrane, is identical for the two animals (Fig. 2) despite the disparate frequency ranges and cochlear lengths, $1 \mathrm{~mm}$ in turtle compared to $10 \mathrm{~mm}$ in rat. This argues for a similar mechanism across classes for acquiring the cochlear gradients. In contrast, the inner hair cells, which are the primary transducers relaying their signals directly to the auditory nerve fiber dendrites, possess MET channels with an invariant conductance of large size [3] comparable to those of mammalian outer hair cells or turtle hair cells tuned to high frequency. Whether the MET channels in inner hair cells are indeed equivalent to channels in high-frequency outer hair cells or differ in some other respects is unclear.

What might be the structural basis of the tonotopic variation in conductance? The simplest hypothesis is that different channel isoforms are expressed along the tonotopic axis as has been proposed to account for the gradient in kinetics of $\mathrm{Ca}^{2+}$-activated $\mathrm{K}^{+}$channels that underlie electrical tuning in turtle and chick auditory hair cells [25]. With the MET channel, structural variation in the pore

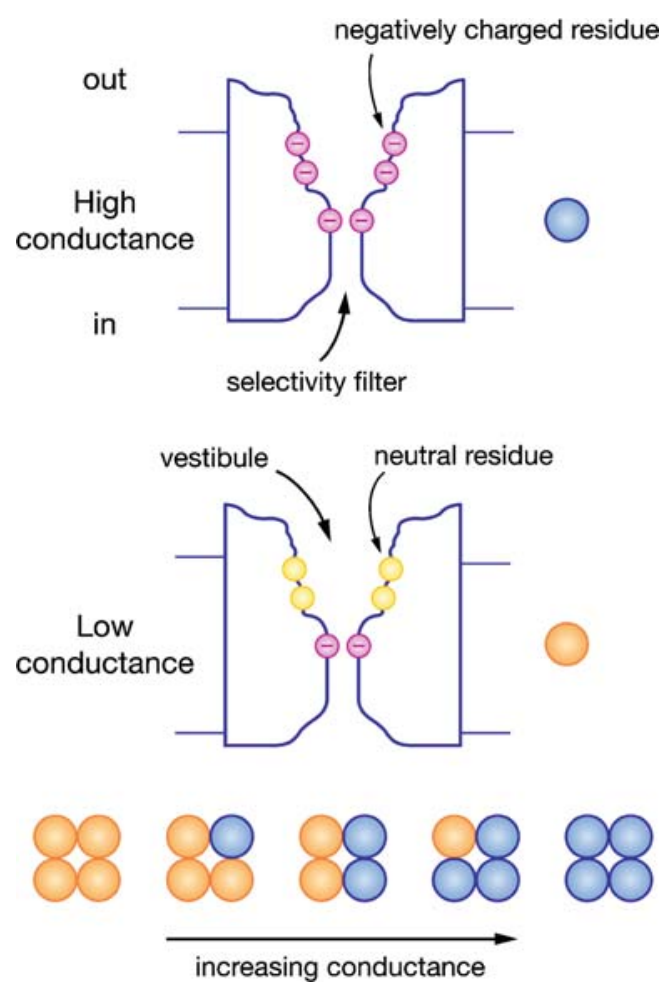

Fig. 3 Diagram of the MET channel pore to account for permeability and block. A wide mouthed vestibule is exposed to the extracellular face and a narrow selectivity filter contains negative charges to account for the $\mathrm{Ca}^{2+}$ permeability. The channel is depicted in high conductance (top) and low conductance (bottom) modes differing by the presence of a ring of negative charges in the vestibule, postulated to influence the local ion concentration. Channels of different conductances (below) are hypothesized to be constructed of heterotetramers of the two isoforms producing channels with intermediate properties region might be expected but conductance changes are not accompanied by differences in ionic selectivity. For example, there is no large difference in the relative $\mathrm{Ca}^{2+}$ permeability $\left(P_{\mathrm{Ca}} / P_{\mathrm{Na}}\right)$ between turtle hair cells tuned to high and low frequency [62], or between low-frequency inner and outer hair cells [3], suggesting no diversity in the selectivity filter. However, a difference in the $\mathrm{IC}_{50}$ for block by DHS has been found, MET currents in high frequency turtle cells being fivefold less sensitive to block than lowfrequency cells [62]. The $\mathrm{IC}_{50}$ for DHS block was smaller in low $\mathrm{Ca}^{2+}$, but nevertheless, the tonotopic differences were preserved. One explanation for the DHS result is that it is an open-channel blocker and that variations in $\mathrm{IC}_{50}$ reflect differences in the probability of opening at rest, smaller in high frequency hair cells and larger in low $\mathrm{Ca}^{2+}$. Thus, factors that increase the probability of opening at rest, including lowering extracellular $\mathrm{Ca}^{2+}$, result in a smaller $\mathrm{IC}_{50}$. This would merely be a sign of differences in fast adaptation. In contrast to DHS, amiloride, another open channel blocker [66, 70], has an $\mathrm{IC}_{50}$ that is invariant with frequency [62].

One hypothesis to explain variations in unitary conductance is that the channel or its local membrane environment contains negative charges that play a role in regulating permeability (Fig. 3). Altering these charges might influence the conductance by electrostatic mechanisms affecting the local ionic concentration, as has been shown for the BK $\mathrm{Ca}^{2+}$-activated $\mathrm{K}^{+}$channel [6]. The $\mathrm{BK}$ channel is a large conductance channel similar to the MET channel, and structurally, it contains a vestibule on its intracellular aspect with a $0.9-n m-w i d e ~ m o u t h ~[5]$. Replacement of negatively charged residues in the S6 region lining the vestibule by non-charged ones halves the single-channel conductance [6]. If similar charges on or around the external face of the MET channel act to concentrate the ions, then the effects of lowering the ionic strength of the extracellular solution should differentially affect the MET current in small and large conductance channels. This hypothesis was tested [3] in apical inner and outer hair cells (having a twofold difference in conductance) by reducing the $\mathrm{Na}^{+}$concentration to a third by substitution with sucrose. The reduced ionic strength should augment the effects of the local charges by increasing the surface potential according to the Gouy-Chapman theory [41]. Perfusing the low ionic strength medium reduced the MET current in outer hair cells to 0.33 , a drop identical to the dilution of the extracellular permeant ions. In contrast, the MET current in inner hair cells showed a smaller reduction to 0.43 . This is evidence for a difference in the MET channels of high and low unitary conductance. It is consistent with the existence of charges around the channel that could augment the conductance by concentrating ions in the vestibule, increasing their availability to carry inward current [3]. 
In extrapolating from the results on the BK channel, the channel orientation was flipped so that in the MET channel the wide vestibule was exposed to the extracellular solution (Fig. 3). This configuration fits with the external accessibility to large permeant organic cations [22] or to permeant blockers [70], but it suggests a structural dissimilarity of the MET channel to the $\mathrm{K}^{+}$channel superfamily to which the BK channel belongs. Extending the analogy with an inverted $\mathrm{K}^{+}$channel predicts that the gate lies on the external surface where it could connect with the tip link. Again the BK channel may serve as a useful model. An internal gating ring comprising eight RCK (regulator of $\mathrm{K}^{+}$ conductance) domains, two per subunit, is thought to use energy from $\mathrm{Ca}^{2+}$ binding to activate the $\mathrm{S} 6$ gate via a linker. Based on experiments of lengthening or shortening the linker region, it has been suggested that the linkergating ring complex acts as a mechanical spring to apply force to the gate [58]. Pursuing this line of argument, in the MET channel, the gating ring would be on the extracellular face and the gating spring would be intrinsic to the channel protein.

\section{TRPP channels as contenders}

Mechanically gated ion channels in various organisms have been identified as members of the TRP channel family [10], making them natural contenders for the MET channel in hair cells. Several have already been investigated for involvement in hair cell mechanotransduction and eliminated, including TRPV4, TRPA1, and TRPML3. Although TRPML3 is present in hair cells and its mutation causes age-dependent hearing loss, hair cell degeneration has been attributed to $\mathrm{Ca}^{2+}$ loading by activation of an inwardly rectifying channel unlike the MET channel [34, 56, 69]. Of course, it remains possible that the MET channel belongs to an entirely new channel family as was the case with the CRAC channel [24, 73]. Furthermore, the analogy to an inverted BK channel, with an external vestibule may not easily fit with TRP channels either. However, one category of TRP channel that does possess similar biophysical properties to the MET channel is the TRPP family, also known as PKD or polycystin channels because their mutation causes renal cyst formation. This family comprises three pore forming members, TRPP2 (PKD2), TRPP3 (PKD2L), and TRPP5 (PKD2L1), as well as several large accessory proteins, TRPP1 (PKD1) and three homologs. When expressed alone, TRPP1 cannot produce ion channels as do other members of the TRP channel family.

TRPP channels are thought to be mechanoreceptors that detect ciliary motion [57] in the kidney, heart, and other tissues, and in most respects, they exhibit comparable properties to the MET channel with large unitary conduc- tance and $\mathrm{Ca}^{2+}$ permeability [60]. For example, TRPP2 has a unitary conductance of $40-170 \mathrm{pS}$, a $P_{\mathrm{Ca}} / P_{\mathrm{Na}}$ of up to 5 and is blocked by $\mathrm{Ca}^{2+}, \mathrm{La}^{3+}, \mathrm{Gd}^{3+}$, and amiloride [33, 35, 49]. TRPP3 has a unitary conductance of $137-400 \mathrm{pS}$, a $P_{\mathrm{Ca}} / P_{\mathrm{Na}}$ of 4 and is blocked by $\mathrm{Ca}^{2+}, \mathrm{Mg}^{2+}, \mathrm{La}^{3+}, \mathrm{Gd}^{3+}$, and amiloride [7, 17, 67]. Most experimenters agree that the TRPP channels when bathed in normal monovalent ions have a current--voltage relationship displaying inward rectification, with unitary conductances for inward current being two to three times those for outward current. A third poreforming member, TRPP5, has a single channel conductance of $300 \mathrm{pS}$, a $P_{\mathrm{Ca}} / P_{\mathrm{Na}}$ of 4 and is blocked by $\mathrm{La}^{3+}, \mathrm{Gd}^{3+}$, and amiloride too [71]. For all three TRPP isoforms, the amiloride half-blocking concentrations are in roughly the same range $\left(\mathrm{IC}_{50}=40-130 \mu \mathrm{M} ;[17,19,71]\right)$ as for the native MT channel. No information is available about block by dihydrostreptomycin. It is unclear why different unitary conductances are reported by different groups (these may depend on the expression system: oocytes, HEK-293, or CHO cells) but all concur on a relatively large size $\geq 100 \mathrm{pS}$.

Minor differences between the MET channel and the TRPP channel are that the latter channels are less susceptible to block by $\mathrm{La}^{3+}$ and $\mathrm{Gd}^{3+}$ and show $\mathrm{Ca}^{2+}$ induced activation, a feature never reported for the native MET channel. Indeed, elevating intracellular $\mathrm{Ca}^{2+}$ blocks the hair cell MET channel [47] and causes adaptation [63]. $\mathrm{Ca}^{2+}$-induced activation in TRPP2 may underlie its intracellular role as a $\mathrm{Ca}^{2+}$ release channel in endoplasmic reticulum [50], though its function is often dependent on interaction with adaptor proteins [8]. One significant difference is in the permeability to organic cations, choline and TEA being significantly permeable for the native channel [59] but not for the TRPP3 [7, 16]. Another difference, at least for TRPP3, is in sensitivity to $\mathrm{pH}$ changes. TRPP3 was found to be part of receptor for sour taste sensation and when expressed heterologously was activated by acidification of the external solution [39, 40], but no effects on the MET channel were reported for changes in $\mathrm{pH}$ from 6.5 to 8.5 [22]. Differences in channel properties may hinge around the presence or absence of accessory subunits. For example, TRPP3 occurs in the taste receptors in conjunction with the non-pore-forming subunit PKD1L3 [39, 40], but if expressed alone in HEK-293 cells, TRPP3 channels are suppressed by acidification but markedly enhanced by alkalization to $\mathrm{pH} 9.0$ [67].

Four TRPP isoforms are present in the organ of Corti [15], two pore forming (TRPP2 and TRPP3) and two modulatory (TRPP1, PKDREJ), which allows for assembly of heteromultimers with disparate properties including conductance. Heteromultimers of TRPP2 and TRPP 3 could in theory generate single-channel conductances from 40 to $400 \mathrm{pS}$ encompassing the range seen in vivo. In addition, TRPP2 channels can form heteromultimeric channels with 
other types of TRP channel: TRPV4 [48] or TRPC1 [2], both of which are present in the organ of Corti [15] and may modify channel properties. For example, TRPP2 expressed with TRPC1 has a unitary conductance of $40 \mathrm{pS}$ compared to $140 \mathrm{pS}$ when it was expressed with TRPP1 [2]. There are thus at least two specific mechanisms for generating an array of conductance levels overlapping those in the cochlea: by mixing TRPP isoforms or by combining TRPP with other TRP channels. Apart from the similarity of their biophysical properties to the MET channel, an attractive feature of the TRPP family is the existence of the ancillary subunit TRPP1 that could act as a strong external linker [27] with an extensive N-terminus to connect to the tip link and supply force to the pore-forming subunit. This could act as a lever arm and its motion account for the 2- to 4-nm gating swing that appears in models of transduction [38].

\section{Conclusions}

The hair cell MET channel is a large conductance cation channel preferentially permeable to $\mathrm{Ca}^{2+}$, the influx of which initiates channel reclosure and fast adaptation. It is unusual in being partially permeable to organic cations as large as TEA, FM1-43, and DHS, a property attributable to a 2-nm-long external vestibule with a wide mouth. This feature is unlike many other ion channels, especially those of the $\mathrm{K}^{+}$channel superfamily including cyclic nucleotide gated channels and TRP channels, which form tetrameric channels with a vestibule on the intracellular face. The depiction of the MET channel as an inverted $\mathrm{K}^{+}$channel with large external vestibule may be inconsistent with its being a member of the $\mathrm{K}^{+}$channel superfamily. Furthermore, to achieve ultrafast mechanical activation, the MET channel may not require the six trans-membrane domain structure that is typical of the $\mathrm{K}^{+}$channel family subunits and associated with voltage or ligand gating. No molecular structure has so far been established for the MET channel and it is possible that it belongs to an entirely new family that may emerge from a genetic screen. Nevertheless, its biophysical signature in many respects resembles the TRPP (or PKD) family. There are however some differences, most notably a smaller pore impermeable to TEA in TRPP channels. On the other hand, TRPP channels have multiple isoforms, and channel formation by oligomerization between isoforms, with different accessory subunits or other TRP channel types, may account for the variation in unitary conductance found in vivo for the MET channel. Unfortunately, the presence of multiple pore-forming subunits in the MET channel may render difficult the interpretation of simple knock-out experiments where other subunits may be up-regulated. With the isolation of a candidate channel that has matching properties, the most rigorous test of its involvement in hair cell transduction will be incorporation of a modified pore sequence, as was done with the Orai1 channel [73]. For example, glutamate replacements in the pore or vestibule may alter permeability, conductance, and adaptation. Identifying the MET channel will be the first step in elucidating how the channel is mechanically gated, and how it can achieve kinetics so fast that it can encode frequencies up to $100 \mathrm{kHz}$ as required for auditory transduction in animals such as bats and cetaceans [23].

Acknowledgments This work was supported by the National Institutes on Deafness and other Communication Disorders, grant no. RO1 DC01362 to Robert Fettiplace. I wish to thank Carole Hackney for helpful discussions introducing me to PKD channels and for comments on the manuscript.

Open Access This article is distributed under the terms of the Creative Commons Attribution Noncommercial License which permits any noncommercial use, distribution, and reproduction in any medium, provided the original author(s) and source are credited.

\section{References}

1. Assad JA, Hacohen N, Corey DP (1989) Voltage dependence of adaptation and active bundle movement in bullfrog saccular hair cells. Proc Natl Acad Sci USA 86:2918-2922

2. Bai CX, Giamarchi A, Rodat-Despoix L, Padilla F, Downs T, Tsiokas L, Delmas P (2008) Formation of a new receptor-operated channel by heteromeric assembly of TRPP2 and TRPC1 subunits. EMBO Rep 9:472-479

3. Beurg M, Evans MG, Hackney CM, Fettiplace R (2006) A largeconductance calcium-selective mechanotransducer channel in mammalian cochlear hair cells. J Neurosci 26:10992-11000

4. Beurg M, Fettiplace R, Nam J-H, Ricci AJ (2009) Localization of inner hair cell mechanotransducer channels using high speed calcium imaging. Nat Neurosci 12:553-558

5. Brelidze TI, Magleby KL (2005) Probing the geometry of the inner vestibule of BK channels with sugars. J Gen Physiol 126:105-121

6. Brelidze TI, Niu X, Magleby KL (2003) A ring of eight conserved negatively charged amino acids doubles the conductance of BK channels and prevents inward rectification. Proc Natl Acad Sci USA 100:9017-9022

7. Chen XZ, Vassilev PM, Basora N, Peng JB, Nomura H, Segal Y, Brown EM, Reeders ST, Hediger MA, Zhou J (1999) Polycystin$\mathrm{L}$ is a calcium-regulated cation channel permeable to calcium ions. Nature 401:383-386

8. Chen XZ, Li Q, Wu Y, Liang G, Lara CJ, Cantiello HF (2008) Submembraneous microtubule cytoskeleton: interaction of TRPP2 with the cell cytoskeleton. FEBS J 275:4675-4683

9. Cheung EL, Corey DP (2006) Ca2+ changes the force sensitivity of the hair-cell transduction channel. Biophys J 90:124-139

10. Christensen AP, Corey DP (2007) TRP channels in mechanosensation: direct or indirect activation? Nat Rev Neurosci 8:510-521

11. Corey DP, Hudspeth AJ (1979) Ionic basis of the receptor potential in a vertebrate hair cell. Nature 281:675-677

12. Corey DP, Hudspeth AJ (1983) Kinetics of the receptor current in bullfrog saccular hair cells. J Neurosci 3:962-976

13. Crawford AC, Evans MG, Fettiplace R (1989) Activation and adaptation of transducer currents in turtle hair cells. J Physiol 419:405-434 
14. Crawford AC, Evans MG, Fettiplace R (1991) The actions of calcium on the mechano-electrical transducer current of turtle hair cells. J Physiol 434:369-398

15. Cuajungco MP, Grimm C, Heller S (2007) TRP channels as candidates for hearing and balance abnormalities in vertebrates. Biochim Biophys Acta 1772:1022-1027

16. Dai XQ, Karpinski E, Chen XZ (2006) Permeation and inhibition of polycystin-L channel by monovalent organic cations. Biochim Biophys Acta 1758:197-205

17. Dai XQ, Ramji A, Liu Y, Li Q, Karpinski E, Chen XZ (2007) Inhibition of TRPP3 channel by amiloride and analogs. Mol Pharmacol 72:1576-1585

18. Dallos P (2008) Cochlear amplification, outer hair cells and prestin. Curr Opin Neurobiol 18:370-376

19. Delmas P, Nauli SM, Li X, Coste B, Osorio N, Crest M, Brown DA, Zhou J (2004) Gating of the polycystin ion channel signaling complex in neurons and kidney cells. FASEB J 18:740-742

20. Denk W, Holt JR, Shepherd GM, Corey DP (1995) Calcium imaging of single stereocilia in hair cells: localization of transduction channels at both ends of tip links. Neuron 15:13111321

21. Dwyer TM, Adams DJ, Hille B (1980) The permeability of the endplate channel to organic cations in frog muscle. J Gen Physiol 75:469-492

22. Farris HE, LeBlanc CL, Goswami J, Ricci AJ (2004) Probing the pore of the auditory hair cell mechanotransducer channel in turtle. J Physiol 558:769-792

23. Fay RR (1988) Hearing in vertebrates: a psychophysics databook. Hill-Fay Associates, Winnetka, IL

24. Feske S, Gwack Y, Prakriya M, Srikanth S, Puppel SH, Tanasa B, Hogan PG, Lewis RS, Daly M, Rao A (2006) A mutation in Orai1 causes immune deficiency by abrogating CRAC channel function. Nature 441:179-185

25. Fettiplace R, Fuchs PA (1999) Mechanisms of hair cell tuning. Ann Rev Physiol 61:809-834

26. Fettiplace R, Ricci AJ (2006) Mechanoelectrical transduction in auditory hair cells. In: Eatock RA, Popper A, Fay RR (eds) Springer handbook of auditory research: hair cells. Springer, New York, pp 154-203

27. Forman JR, Qamar S, Paci E, Sandford RN, Clarke J (2005) The remarkable mechanical strength of polycystin-1 supports a direct role in mechanotransduction. J Mol Biol 349:861-871

28. Furness DN, Katori Y, Nirmal Kumar B, Hackney CM (2008) The dimensions and structural attachments of tip links in mammalian cochlear hair cells and the effects of exposure to different levels of extracellular calcium. Neuroscience 154:10-21

29. Gale JE, Marcotti W, Kennedy HJ, Kros CJ, Richardson GP (2001) FM1-43 dye behaves as a permeant blocker of the hair-cell mechanotransducer channel. J Neurosci 21:7013-7025

30. Géléoc GS, Lennan GW, Richardson GP, Kros CJ (1997) A quantitative comparison of mechanoelectrical transduction in vestibular and auditory hair cells of neonatal mice. Proc R Soc Lond B 264:611-621

31. Gillespie PG, Corey DP (1997) Myosin and adaptation by hair cells. Neuron 19:955-958

32. Glowatzki E, Ruppersberg JP, Zenner HP, Rüsch A (1997) Mechanically and ATP-induced currents of mouse outer hair cells are independent and differentially blocked by d-tubocurarine. Neuropharmacology 36:1269-1275

33. González-Perrett S, Kim K, Ibarra C, Damiano AE, Zotta E, Batelli M, Harris PC, Reisin IL, Arnaout MA, Cantiello HF (2001) Polycystin-2, the protein mutated in autosomal dominant polycystic kidney disease (ADPKD), is a Ca2+-permeable nonselective cation channel. Proc Natl Acad Sci USA 98:1182-1187

34. Grimm C, Cuajungco MP, van Aken AF, Schnee M, Jörs S, Kros CJ, Ricci AJ, Heller S (2007) A helix-breaking mutation in
TRPML3 leads to constitutive activity underlying deafness in the varitint-waddler mouse. Proc Natl Acad Sci USA 104:1958318588

35. Hanaoka K, Qian F, Boletta A, Bhunia AK, Piontek K, Tsiokas L, Sukhatme VP, Guggino WB, Germino GG (2000) Co-assembly of polycystin-1 and -2 produces unique cation-permeable currents. Nature 408:990-994

36. He DZ, Jia S, Dallos P (2004) Mechanoelectrical transduction of adult outer hair cells studied in a gerbil hemicochlea. Nature 429:766-770

37. Hille B (2001) Ionic channels of excitable membranes, 3rd edn Sinauer, Sunderland, Mass

38. Howard J, Hudspeth AJ (1988) Compliance of the hair bundle associated with gating of mechanoelectrical transduction channels in the bullfrog's saccular hair cell. Neuron 1:189-199

39. Huang AL, Chen X, Hoon MA, Chandrashekar J, Guo W, Tränkner D, Ryba NJ, Zuker CS (2006) The cells and logic for mammalian sour taste detection. Nature 442:934-938

40. Ishimaru $\mathrm{Y}$, Inada $\mathrm{H}$, Kubota $\mathrm{M}$, Zhuang $\mathrm{H}$, Tominaga $\mathrm{M}$, Matsunami H (2006) Transient receptor potential family members PKD1L3 and PKD2L1 form a candidate sour taste receptor. Proc Natl Acad Sci USA 103:12569-12574

41. Jackson MB (2006) Molecular and cellular biophysics. Cambridge University Press, Cambridge

42. Jørgensen F, Ohmori H (1988) Amiloride blocks the mechanoelectrical transduction channel of hair cells of the chick. J Physiol 403:577-588

43. Jørgensen F, Kroese AB (1995) Ca selectivity of the transduction channels in the hair cells of the frog sacculus. Acta Physiol Scand 155:363-376

44. Kachar B, Parakkal M, Kurc M, Zhao Y, Gillespie PG (2000) High-resolution structure of hair-cell tip links. Proc Natl Acad Sci USA 97:13336-13341

45. Kazmierczak P, Sakaguchi H, Tokita J, Wilson-Kubalek EM, Milligan RA, Müller U, Kachar B (2007) Cadherin 23 and protocadherin 15 interact to form tip-link filaments in sensory hair cells. Nature 449:87-91

46. Kimitsuki T, Nakagawa T, Hisashi K, Komune S, Komiyama S (1996) Gadolinium blocks mechano-electric transducer current in chick cochlear hair cells. Hear Res 101:75-80

47. Kimitsuki T, Taira T, Komune S, Komiyama S (1998) Intracellular calcium suppresses mechano-electrical transduction current in chick cochlear hair cells. ORL J Otorhinolaryngol Relat Spec 60:263-266

48. Köttgen M, Buchholz B, Garcia-Gonzalez MA, Kotsis F, Fu X, Doerken M, Boehlke C, Steffl D, Tauber R, Wegierski T, Nitschke R, Suzuki M, Kramer-Zucker A, Germino GG, Watnick T, Prenen J, Nilius B, Kuehn EW, Walz G (2008) TRPP2 and TRPV4 form a polymodal sensory channel complex. J Cell Biol 182:437-447

49. Koulen P, Cai Y, Geng L, Maeda Y, Nishimura S, Witzgall R, Ehrlich BE, Somlo S (2002) Polycystin-2 is an intracellular calcium release channel. Nat Cell Biol 4:191-197

50. Koulen P, Duncan RS, Liu J, Cohen NE, Yannazzo JA, McClung N, Lockhart CL, Branden M, Buechner M (2005) Polycystin-2 accelerates $\mathrm{Ca} 2+$ release from intracellular stores in Caenorhabditis elegans. Cell Calcium 37:593-601

51. Kroese AB, Das A, Hudspeth AJ (1989) Blockage of the transduction channels of hair cells in the bullfrog's sacculus by aminoglycoside antibiotics. Hear Res 37:203-217

52. Kros CJ, Rüsch A, Richardson GP (1992) Mechano-electrical transducer currents in hair cells of the cultured neonatal mouse cochlea. Proc R Soc Lond B 249:185-193

53. Lumpkin EA, Hudspeth AJ (1995) Detection of Ca2+ entry through mechanosensitive channels localizes the site of mechanoelectrical transduction in hair cells. Proc Natl Acad Sci USA 92:10297-10301 
54. Marcotti W, van Netten SM, Kros CJ (2005) The aminoglycoside antibiotic dihydrostreptomycin rapidly enters mouse outer hair cells through the mechano-electrical transducer channels. J Physiol 567:505-521

55. Meyers JR, MacDonald RB, Duggan A, Lenzi D, Standaert DG, Corwin JT, Corey DP (2003) Lighting up the senses: FM1-43 loading of sensory cells through nonselective ion channels. J Neurosci 23:4054-4065

56. Nagata K, Zheng L, Madathany T, Castiglioni AJ, Bartles JR, García-Añoveros J (2008) The varitint-waddler (Va) deafness mutation in TRPML3 generates constitutive, inward rectifying currents and causes cell degeneration. Proc Natl Acad Sci USA 105:353-358

57. Nauli SM, Alenghat FJ, Luo Y, Williams E, Vassilev P, Li X, Elia AE, Lu W, Brown EM, Quinn SJ, Ingber DE, Zhou J (2003) Polycystins 1 and 2 mediate mechanosensation in the primary cilium of kidney cells. Nat Genet 33:129-137

58. Niu X, Qian X, Magleby KL (2004) Linker-gating ring complex as passive spring and $\mathrm{Ca}(2+)$-dependent machine for a voltageand $\mathrm{Ca}(2+)$-activated potassium channel. Neuron 42:745-756

59. Ohmori H (1985) Mechano-electrical transduction currents in isolated vestibular hair cells of the chick. J Physiol 359:189-217

60. Owsianik G, Talavera K, Voets T, Nilius B (2006) Permeation and selectivity of TRP channels. Annu Rev Physiol 68:685-717

61. Picco C, Menini A (1993) The permeability of the cGMPactivated channel to organic cations in retinal rods of the tiger salamander. J Physiol 460:741-758

62. Ricci A (2002) Differences in mechano-transducer channel kinetics underlie tonotopic distribution of fast adaptation in auditory hair cells. J Neurophysiol 87:1738-1748

63. Ricci AJ, Fettiplace R (1998) Calcium permeation of the turtle hair cell mechanotransducer channel and its relation to the composition of endolymph. J Physiol 506:159-173
64. Ricci AJ, Crawford AC, Fettiplace R (2003) Tonotopic variation in the conductance of the hair cell mechanotransducer channel. Neuron 40:983-990

65. Ricci AJ, Kennedy HJ, Crawford AC, Fettiplace R (2005) The transduction channel filter in auditory hair cells. J Neurosci 25:7831-7839

66. Rüsch A, Kros CJ, Richardson GP (1994) Block by amiloride and its derivatives of mechano-electrical transduction in outer hair cells of mouse cochlear cultures. J Physiol 474:75-86

67. Shimizu T, Janssens A, Voets T, Nilius B (2009) Regulation of the murine TRPP3 channel by voltage, $\mathrm{pH}$, and changes in cell volume. Pflügers Arch 457:795-807

68. Stepanyan R, Frolenkov GI (2009) Fast adaptation and Ca2+ sensitivity of the mechanotransducer require myosin-XVa in inner but not outer cochlear hair cells. J Neurosci 29:4023-4034

69. van Aken AF, Atiba-Davies M, Marcotti W, Goodyear RJ, Bryant JE, Richardson GP, Noben-Trauth K, Kros CJ (2008) TRPML3 mutations cause impaired mechano-electrical transduction and depolarization by an inward-rectifier cation current in auditory hair cells of varitint-waddler mice. J Physiol 586:5403-5418

70. van Netten SM, Kros CJ (2007) Insights into the pore of the hair cells transducer channel from experiments with permeant blockers. Curr Top Membr 59:375-398

71. Volk T, Schwoerer AP, Thiessen S, Schultz JH, Ehmke H (2003) A polycystin-2-like large conductance cation channel in rat left ventricular myocytes. Cardiovasc Res 58:76-88

72. Wu YC, Ricci AJ, Fettiplace R (1999) Two components of transducer adaptation in auditory hair cells. J Neurophysiol $82: 2171-2181$

73. Yeromin AV, Zhang SL, Jiang W, Yu Y, Safrina O, Cahalan MD (2006) Molecular identification of the CRAC channel by altered ion selectivity in a mutant of Orai. Nature 443:226-229 